\title{
SMOOTH MUSCLE-LIKE CELLS IN THE THECA EXTERNA OF OVARIAN FOLLICLES IN THE SHEEP
}

\author{
J. D. O'SHEA \\ Department of Veterinary Preclinical Sciences, \\ University of Melbourne, Victoria, Australia
}

(Received 17th Fuly 1970)

\begin{abstract}
Summary. Mature ovarian follicles from three sheep were examined by electron microscopy. Many cells in the theca externa contained cytoplasmic filaments and dense bodies characteristic of smooth muscle cells. These observations suggest a contractile function in the theca externa.
\end{abstract}

Light microscope studies to determine whether muscle cells are present in the walls of ovarian follicles have produced conflicting results (e.g. Guttmacher \& Guttmacher, 1921; Glaesson, 1947). It has recently been shown by electron microscopy (Osvaldo-Decima, 1970; O'Shea, 1970a, b) that cells with the characteristic ultrastructural features of smooth muscle are present in the theca externa of ovarian follicles in the rat and the rhesus monkey. This communication records the presence of smooth muscle-like cells in the walls of ovarian follicles in the sheep.

Mature ovarian follicles from three Border Leicester $\times$ Merino ewes, aged 5 to 6 years, were examined by electron microscopy. These sheep had come into oestrus 21 to $29 \mathrm{hr}$ before the follicles were collected. Under thiamylal sodium (Surital, Parke Davis) anaesthesia the ovaries were inspected visually and the largest unruptured follicle from each sheep was selected. These follicles were approximately 7 to $8 \mathrm{~mm}$ in diameter, and would have been expected to rupture within $3 \frac{1}{2} \mathrm{hr}$. This estimate was based on the time of onset of the preovulatory luteinizing hormone surge (Cumming, Brown, Blockey, Winfield, Baxter \& Goding, 1971) which occurred $22 \frac{1}{2}, 23 \frac{1}{4}$ and $24 \frac{1}{2} \mathrm{hr}$ respectively before the follicles were obtained.

Radially orientated slices of tissue passing through all layers of the follicular wall and into the surrounding stromal tissue were fixed for $1 \mathrm{hr}$ in cold $5 \%$

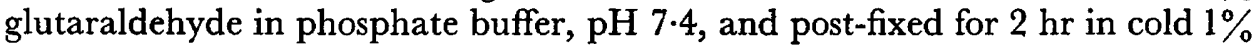
osmium tetroxide in phosphate buffer, $\mathrm{pH} \mathrm{7.4}$. Tissues were embedded in Araldite and sectioned on a Reichert OMU2 ultra-microtome. Thin sections were stained with $2 \%$ aqueous uranyl acetate and with lead citrate, and examined in a Hitachi HU 11B electron microscope.

The follicular theca externa (Pl. 1, Fig. 1) consisted of several layers of fusiform cells, some possessing very thin cytoplasmic processes. The presence of numerous, long, thin cytoplasmic profiles suggested a tangential flattening 
of many of the cells. Tight junctions (Pl. 1, Fig. 2) were frequently seen between thecal cells and collagen fibrils were abundant in the intercellular spaces. On its inner surface, the theca externa was readily differentiated from the more vascular theca interna, which was characterized by shorter, broader cells containing prominent lipid droplets. On its outer surface, the theca externa blended with the surrounding stroma without a sharp line of demarcation.

Considerable variation was seen in the structure of the cells in the theca externa, both between cells and along the lengths of individual cells. Some, regarded as relatively undifferentiated stromal cells (Pl. 1, Fig. 2), contained many ribosomes, both free and associated with membranes of the endoplasmic reticulum. Golgi complexes and small or moderate numbers of mitochrondria were also present. Other thecal cells, which possessed a high concentration of longitudinally-oriented cytoplasmic filaments together with characteristic dense bodies (Pl. 1, Fig. 2), clearly represented a type of smooth muscle. Micropinocytotic vesicles were seen along the surfaces of some of these cells, and a basement membrane was sometimes demonstrable. Many other thecal cells were intermediate in structure (Pl. 1, Figs. 3 to 6 ). These possessed localized aggregations of cytoplasmic filaments, with or without dense bodies, while much of their cytoplasm resembled that of cells of the undifferentiated stromal type. One such cell was seen to possess a cilium (Pl. 1, Fig. 3). The filaments in these cells were generally close to the cell membrane (Pl. 1, Fig. 5), but in some cells appeared to lie deeper within the cytoplasm (Pl. 1, Fig. 6).

Although stromal cells beyond the theca externa were not studied in detail, filament-containing cells were also observed at a considerable distance from the walls of follicles.

These observations indicate that many of the cells in the theca externa of ovarian follicles in the sheep have the essential ultrastructural features normally associated with smooth muscle. The structure of some of these cells is reminiscent of the 'primitive' smooth muscle cells described by Rhodin (1968) in the walls of small venules. In that situation, the cells are presumably not as a rule in a state of active differentiation. Whether the ovarian cells described here are a 'primitive' type of muscle cell in a steady state or, alternatively, represent

\section{EXPLANATION OF PLATE 1}

All figures are electron micrographs of cells from the theca externa.

FIG. 1. General view of the theca externa, showing muscle-like cells (M), relatively undifferentiated cells $(\mathrm{U})$, and abundant collagen fibrils (C). Lipid-containing cells of the theca interna (TI) are present at the top of the picture. $\times 7700$.

Fig. 2. A smooth muscle-like cell (M), whose cytoplasm contains filaments and dense bodies (arrows) lies alongside a cell lacking features of muscle differentiation (U). A tight junction ( $\mathrm{J}$ ) connects these two cells. The basement membrane (BM) is visible along part of the surface of the muscle-like cell. $\times 39,000$. Insert: detail of a tight junction between thecal cells. $\times 108,000$.

Frgs. 3 and 4. Two widely separated regions of the same cell. Near the nucleus (N-Fig. 3 ) the cytoplasm is rich in organelles and the base of a cilium $(\mathrm{C})$ is seen. In Fig. 4, the cytoplasm contains filaments, and two dense bodies (arrowed) are present. $\times 21,000$.

Fig. 5. Part of a cell of intermediate structure, showing a bundle of cytoplasmic filaments (arrowed) running near to the cell surface. $\times 57,000$.

Fig. 6. Part of another cell, showing filament bundles, with associated dense bodies (arrowed), lying more deeply in the cytoplasm. $\times 41,400$. 
PLATE 1
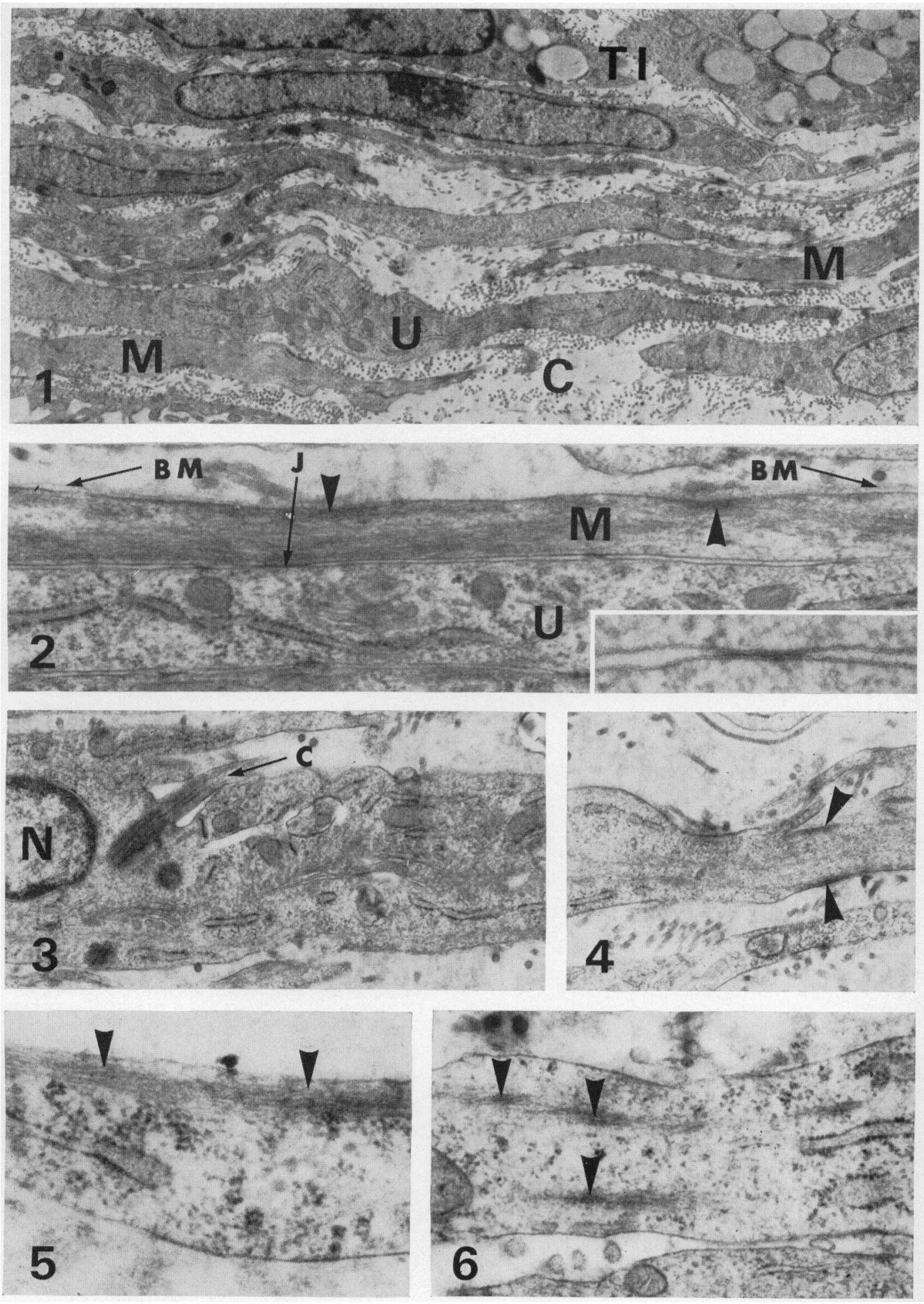

(Facing p. 284) 
immature stages in an active process of myogenesis, cannot be determined from this material. However, the wide range of structural variants seen suggests an active process of differentiation.

On the basis of the ultrastructural features described, it can be proposed that many of the cells in the theca externa of ovarian follicles in sheep have a contractile function. Possible rôles of contractile cells of the follicular wall in the process of ovulation have recently been discussed by Oscaldo-Decima (1970) and O'Shea (1970b). The bulk of evidence appears to point away from a rise in intrafollicular pressure, which might be induced by thecal contraction, being the major factor in inducing follicular rupture. However, thecal contraction could play an important rôle in collapse of the follicle following rupture (O'Shea, 1970b).

This work was supported by a grant from the Rural Gredits Development Fund. I am grateful to the GSIRO Division of Animal Health for electron microscope facilities, and to Dr J. R. Goding and Mr I. A. Gumming for providing the ovarian material studied.

\section{REFERENCES}

Glaesson, L. (1947) Is there any smooth musculature in the wall of the Graafian follicle? Acta anat. 3, 295.

Cumming, I. A., Brown, J. M., Blockey, M. A. de B., Winfiedd, G. G., Baxter, R. W. \& Goding, J. R. (1971) Constancy of interval between luteinizing hormone release and ovulation in the ewe. (Abstract). F. Reprod. Fert. 24, 134.

GuttMacher, M. S. \& GutTmacher, A. F. (1921) Morphological and physiological studies on the musculature of the mature Graafian follicle of the sow. Fohns Hopkins Hosp. Bull. 32, 394.

O'SHEA, J. D. (1970a) An electron microscope study of smooth muscle, and its innervation, in the ovary of the rat. F. Anat. 106, 196.

O'SheA, J. D. (1970b) An ultrastructural study of smooth muscle-like cells in the theca externa of ovarian follicles in the rat. Anat. Rec. 167, 127.

Osvaldo-Decima, L. (1970) Smooth muscle in the ovary of the rat and monkey. 7. ultrastruct. Res. 29, 218.

Rhodin, J. A. G. (1968) Ultrastructure of mammalian venous capillaries, venules and small collecting veins. $\mathcal{F}$. ultrastruct. Res. 25, 452. 